\title{
KARST AND AGRICULTURE IN AUSTRALIA
}

\author{
David Gillieson and Mia Thurgate
}

\begin{abstract}
Much of the development and degradation of karst lands in Australia has occurred in the last two centuries since European settlement. Recent prolonged El Nino events add further climatic uncertainty and place real constraints on sustainable agriculture. The lower southeast of South Australia is perhaps the one area in Australia where karst, and particularly karst hydrology, impinge on the daily lives of the community in that pollution and overexploitation of the aquifer are readily apparent to the local population. Effluent from intensive dairy farms, piggeries and cheese factories enters the karst and has caused concern over pollution of water supplies. Human impacts on the Mole Creek karst of Tasmania have been well documented. The principal recent impacts on the karst are associated with land clearance for farmland, forest cutting for timber, road building, refuse disposal and associated hydrological change. There is similar evidence of agricultural impacts on karst in central New South Wales, with clear evidence of vegetation clearance and soil stripping on the limestones at Wellington, Orange and Molong.
\end{abstract}

KEY WORDS: Australia, human impact on karst, water pollution, soil erosion.

\section{Introduction}

Forest clearance in the extensive karsts of Europe and Asia has been undertaken to obtain land for agriculture from Mesolithic and Neolithic times to the present. The process of extreme land degradation known as rocky desertification thus has some antiquity (Williams, 1993). In contrast, much of the degradation of karst lands in Australia has occurred in the last two centuries since European settlement. Karst only occupies about 4\% of the land area (Fig. 1; Jennings, 1975; Gillieson \& Spate, 1998), with four main groups being present:

- Impounded karsts in Ordovician, Devonian and Silurian rocks of the Eastern Uplands and Tasmania;

- Karst plains on Precambrian and Cambrian limestones and dolomites of northern Australia;

- Karst on Quaternary and late Tertiary dune limestones of the coastal fringe of southern Australia;

- The Nullarbor karst developed in Oligocene to Miocene limestones of the Eucla basin.

In this account we will concentrate on those karsts which have been most subject to agricultural land use. 


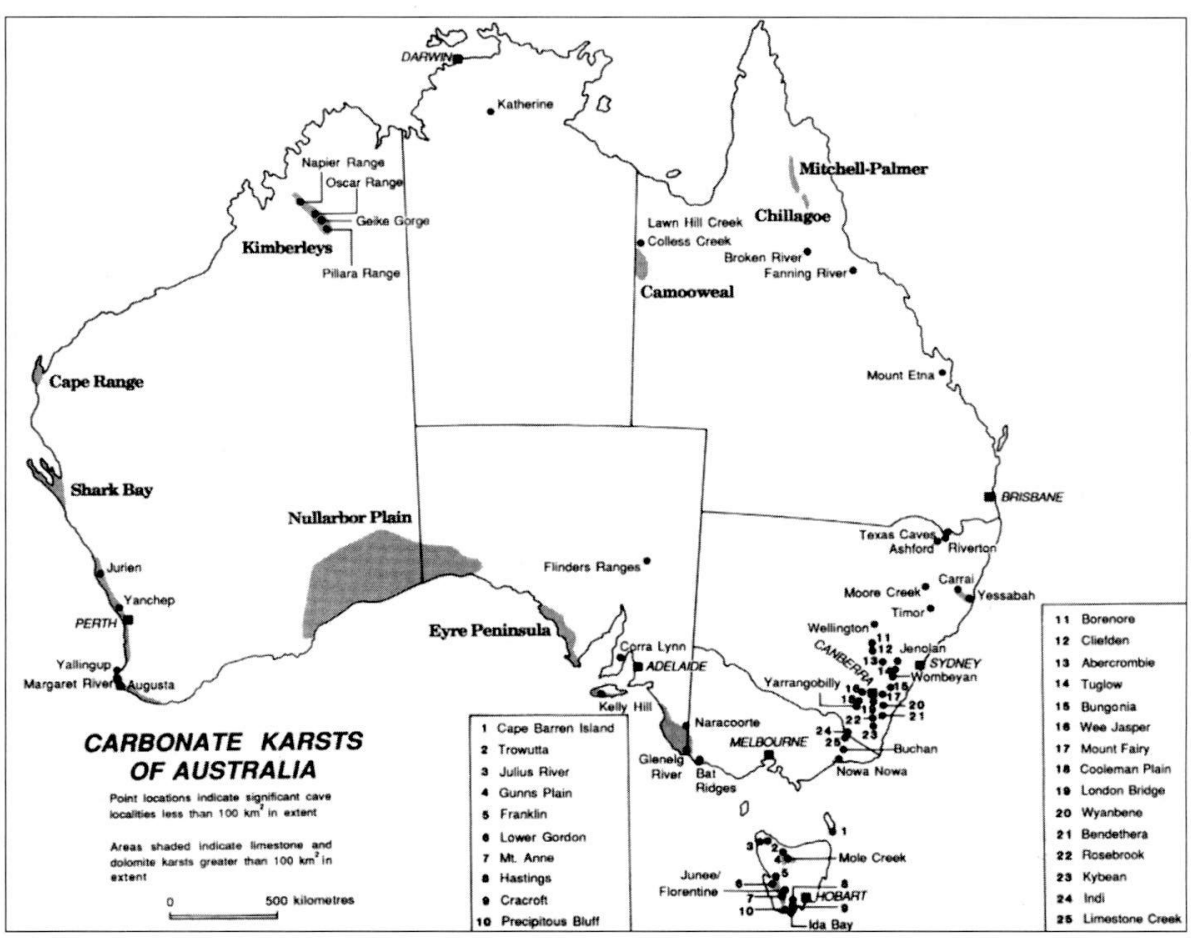

Fig. 1 - Map of carbonate karst areas in Australia. From Gillieson and Smith (1989).

\subsection{Eastern Uplands}

Although both the Chillagoe and Mount Etna areas properly belong to the Eastern Uplands, both areas stand up out of the surrounding landscapes as residual towerkarst and mogote forms. The remainder of the one hundred-odd cavernous karst areas of southern Queensland, New South Wales and eastern Victoria are karst barees - small impounded karsts mostly recessive in the landscape. The limestones are Palaeozoic, chiefly Silurian or Devonian, and are the remnants of limestone deposits emplaced during a number of orogenies in the Tasman Mobile Zone. However, it appears that carbonate deposition was limited in extent and the cycle of uplift, deformation and dissection has both removed and revealed small patches of limestone (Osborne \& Branagan, 1988).

These impounded karsts are amongst Australia's best known and studied areas and include well-known areas such as Jenolan, Wombeyan, Yarrangobilly and Cooleman Plains, all in New South Wales, and Buchan in eastern Victoria. This depth of study is largely the result of the peculiar population distribution in which the vast majority of Australians live southeast of a line between Newcastle and Adelaide.

The Tasmanian karsts, largely in Ordovician rocks, also belong in the Eastern Uplands. There are over 150 karst areas recorded (Kiernan, 1996). Tasmanian caves 
are particularly well developed due to the larger range of local relief, more effective and greater amounts of rainfall and the fact that dolerite sills have protected the limestone high on the valley sides. Many of the caves there bear witness to the effects of multiple glaciations (Kiernan, 1984a). The extensive karst of Mole Creek in the north has been cleared for farms as well as for forestry, while the Junee-Florentine karst is still mostly forested (Eberhard, 1994).

\subsection{Southeast South Australia}

Horizontally bedded Oligocene to Pleistocene limestones underlies the southeast of South Australia and a small portion of western Victoria. These limestones are highly permeable and possess a wide array of karst features including some highly spectacular cenotes (Grimes, 1994). Although the land use is radically different, the area is broadly similar to the karst of the Yucatan peninsula. Much of the cave development appears to have taken place at times of lower sea levels and scuba divers are now discovering faunal remains and well decorated caves dating to the last glaciation. The lower southeast is perhaps the one area in Australia where karst, and particularly karst hydrology, impinge on the daily lives of the community in that pollution and overexploitation of the aquifer are readily apparent to the local population (Emmett and Telfer, 1994). Effluent from intensive dairy farms, piggeries and cheese factories enters the karst and has caused concern over nitrate pollution of water supplies. The area also produces some of Australia's finest red wines from grapes grown on the terra rossa soils at Coonawarra and Padthaway.

In common with most areas of Australia, these karsts are characterised by a low rainfall and a high level of climatic variability (Fig. 2). While the continental core can experience coefficents of variability (C.V.) of rainfall of up to $50 \%$, even the coastal karsts experience $20-30 \%$ C.V. Droughts of up to six months are common, depressing groundwater levels by several metres, while high summer temperatures stress vegetation and fauna. Recent prolonged El Nino events add further climatic uncertainty and place real constraints on agriculture.

Previous work on the impact of agriculture on karst in Australia is limited. Kiernan (1984b, 1989, and 1996) has made by far the greatest contribution for the karsts of Tasmania, while Gillieson (1989) has provided a brief overview of land use impacts on mainland karst. Grimes (1994) has described the nature of the syngenetic karst of Southeastern South Australia, while Emmett and Telfer (1994) have provided details on water pollution in karst in that region. But much of the record is anecdotal and data are few. The conference proceedings of the Australasian Cave and Karst Management Association also provide some examples of specific impacts.

\section{Changes to water quantity and quality}

\subsection{Surface water impacts}

The removal of natural vegetation cover causes changes in karst hydrological 


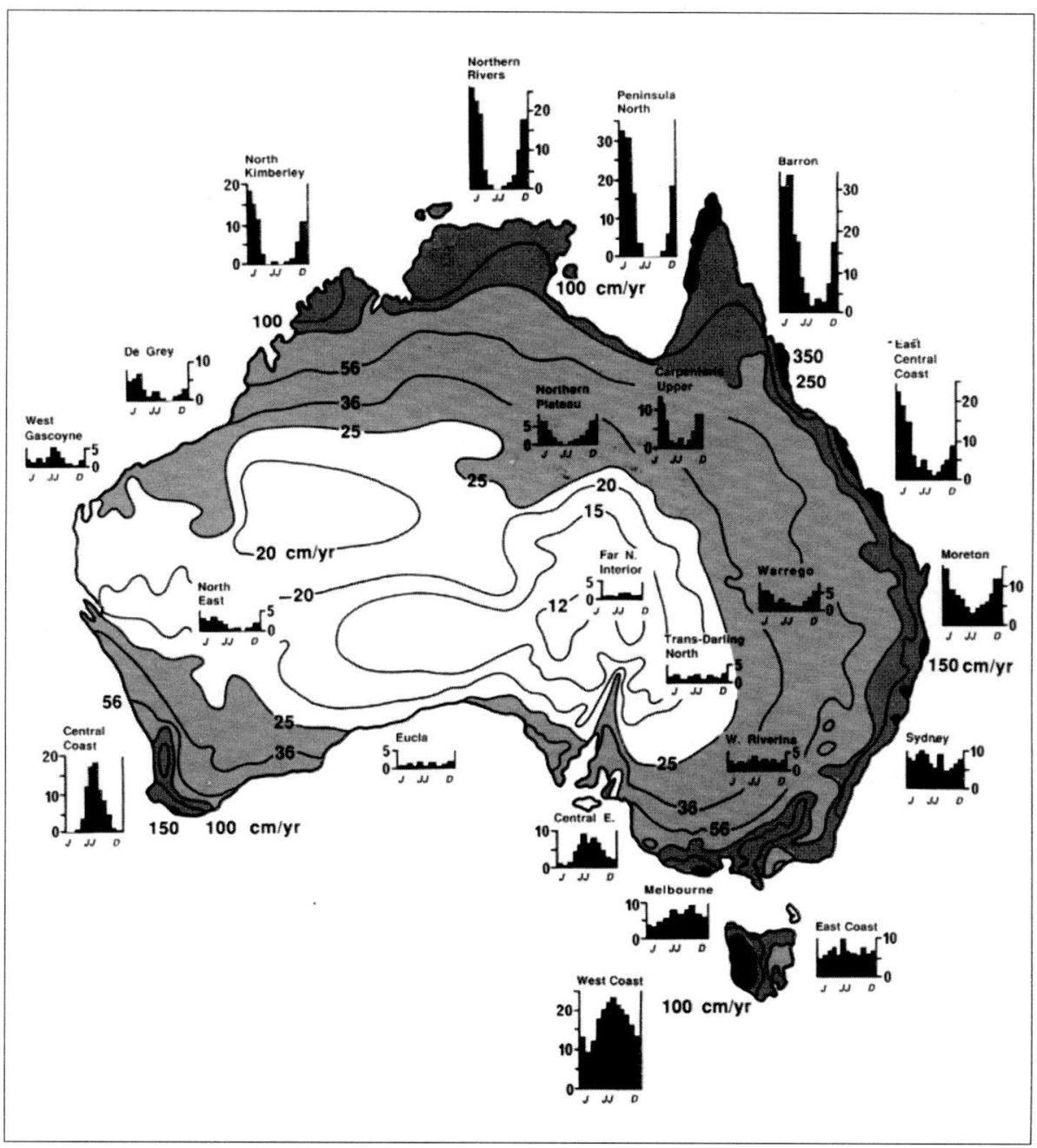

Fig. 2 - Monthly and annual precipitation in centimetres over Australia From Smith (1989).

regimes, particularly by disrupting storage and release mechanisms in the regolith. Fire associated with hazard reduction in agricultural areas can cause sealing of the epikarst, reducing infiltration capacity, so that surface waters may pond, and runoff may carry high sediment loads, eventually impacting on groundwater quality (Holland, 1994). In Mole Creek, Tasmania, mobilisation of sediments after clearing has meant that conduits become choked, so that flooding of pastures during the winter months has rendered these areas unusable for many months of the year (Kiernan, 1989).

Recharge rates are affected by removal of the native vegetation cover and replacement with crops, plantation forests and pastures. In the Southeast of South 
Australia there is quantitative evidence that areas under mature pine plantations have no significant recharge, whereas recharge, probably in excess of that which occurred before European settlement, does occur under pasture (Allison \& Hughes, 1972; Colville \& Holmes, 1972). Speleothems at both Jourama and Yarangobilly, NSW have been damaged by dehydration and/or re-solution since the planting of pines above caves, pines having greater evapotranspiration and canopy interception than native vegetation. At Naracoorte in South Australia, thick mats of pine roots from a 90 year old plantation had intercepted cave air space, and many decorations had dried. Logging of these pines resulted in a regeneration of speleothems, and refilling of rimstone formations (Kiernan, 1988).

Irrigation dams have been built on or adjacent to karst, drowning many features and completely altering hydrological regimes. A large, shallow irrigation dam was built to supply tobacco farmers on the New South Wales/Queensland border, completely drowning the Texas Caves system (Gillieson, 1989). These caves are now only accessible by divers, or during long periods of drought when falling water levels expose some cave entrances, but even then, many of the caves and their surviving contents have been damaged by thick coatings of mud. Similarly, the caves beneath Burrinjuck Dam, New South Wales are now drowned and largely inaccessible (Jennings, 1983).

The most spectacular example of agriculture impacting on surface drainage at a large scale can be found in the Southeast of South Australia. This area was first settled in the 1840s, however, settlement was typically scattered into isolated pockets on high ground. This settlement pattern was a direct result of the karst topography. Natural drainage is impeded by extensive strandlines running parallel to the coast, the water table occurs close to the surface, and rainfall is relatively high. This resulted in between half to three-quarters of the land surface in any given area being seasonally waterlogged or flooded, and water was reported to pond in vast sheets, up to a maximum of 3-4 $\mathrm{m}$ deep, behind the dunes. The early settlers felt isolated and forgotten, and their cries for a drainage scheme to improve the productivity of the land apparently went unheard by the South Australian government. So strong was the despair of the settlers, that they soon proposed secession from the rest of the State (Williams, 1974).

In 1863, the South Australian government, eager to prevent the loss of potentially valuable lands from their estate, began a piecemeal approach to drainage, firstly to improve road access, but later to open up grazing land. A combination of administrative ineptitude, poor financial management, technical difficulties and general apathy meant that for nearly 80 years a series of ineffectual drainage programs were undertaken, most without significant improvement, except in localised areas. It was not until the late 1940s, that effective drainage took place (Fig. 3). Drainage has uncovered $53 \%$ of formerly flood-prone lands and has resulted in the alteration of surface flows, allowing agricultural improvement to the detriment of the wetland ecosystems that once were so widespread.

Jones (1978) reports that since the completion of the drainage scheme, only 11.2 


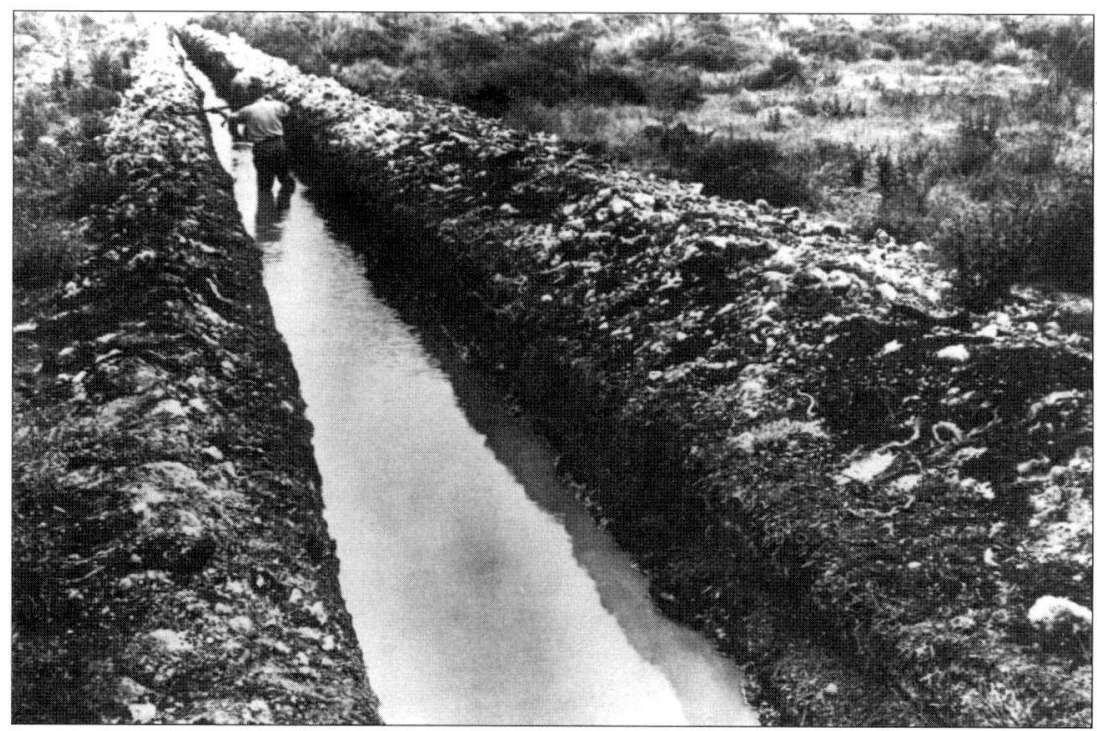

Fig. 3 - Drain being excavated by hand in South East karst district c. 1947. Photograph by South East Drainage Board, S.A.)

$\%$ of the original wetlands remain and of these only $1.3 \%$ are reserved. Along the southern coast, approximately 1800 hectares of swamps, characterised by lines of spring lakes and surrounded by peat fens, were drained, burnt and ploughed for soldier settlement schemes following the Second World War. The two largest remnants, Piccaninnie Ponds and Ewens Ponds are now reserved. Since the swamps have been cleared, there has been a change in the composition of the dominant aquatic plants. Exotic plants such as Rorippa nasturtium-aquaticum have been introduced and these are out-competing the native species, with at least one species now locally extinct. Nutrients levels are steadily increasing in the ponds, while chemical sprays are being used to control plant growth in associated drains. Water levels at Ewens Ponds have been permanently lowered by at least $1.5 \mathrm{~m}$ from original survey levels. Given that these wetlands are recognised as having high natural heritage values, the negative impacts of agricultural development are of continued concern.

\subsection{Groundwater impacts}

Karst aquifers are highly susceptible to groundwater pollution. This is because pollutants can easily and rapidly pass into and through the aquifer with minimal filtration, and with insufficient time for natural degradation (Tranter et al., 1997). Even where contamination sources are localised (point source pollution), the impact of these pollutants are often widespread. This is due to the interconnectedness of the flow paths in karst which allows pollutants to spread across the aquifer. Thus it is possible to detect pollutants in areas of the aquifer far removed from the initial source (Pasquarell \& Boyer, 1991). The speed at which contaminants can pollute a karst 
aquifer are highly variable, and depend on vegetation and soil cover, as well as rainfall patterns and the nature and extent of water transmission through the aquifer.

Blockage of cave and doline entrances are a common occurrence in agricultural lands on karst. For property owners, these openings and depressions represent a potential hazard to stock, and reduce the value of grazing land. Regrettably, in many instances this has lead to the deliberate infilling of these features with agricultural and domestic waste. There are numerous examples of refuse sites being located within karst depressions, and causing point source pollution. At Wee Jasper, in New South Wales, the entrance to Dip Cave has served as a rubbish dump for the local community (Jennings, 1983), while the Heywood municipal tip in western Victoria is located on, and completely infills Dyes Cave (Davey \& White, 1986). At Borenore Caves also in New South Wales, dolines have been used as rubbish dumps and an old grike has been used as a sheep dip, the latter probably releasing arsenic into the groundwater (Holland, 1991). Farm refuse has also been dumped in numerous sinkholes in the Mole Creek area, including drums of the chemical 2,4-D, prompting the site to be named 2,4-D Cave by local cavers (Kiernan, 1989).

Coliform counts in excess of 30,000/100 $\mathrm{ml}$ have been recorded at Mole Creek in Tasmania, which is well above standards for human contact. Preliminary investigations indicate that livestock are the main source of this contaminant. Cattle also have unrestricted access to surface waters in some areas of Mole Creek, causing degradation of the stream banks as well as adding faecal contamination. (Kiernan, 1989). There is also anecdotal evidence that the groundwater pollution at Mole Creek has lead to abnormal rates of human health problems in the local area (Lichon, 1993). Thousands of sheep carcasses were dumped into Earl's Cave in Southeast South Australia, following a major bushfire in 1959. Over 20 years later, putrefied remains were still present, and the water in the pool was still highly polluted and considered hazardous to human health (Horne, 1993).

The incident at Earl's Cave is regrettably not an isolated event, and rubbish and wastewaters have been disposed directly into the unconfined aquifer of the Southeast karst for over 100 years. Waterhouse (1977) reported that nitrate is the most significant contaminant of the area, and the sources include derivatives of animal wastes and dairy industry wastes. He developed a contour map of the nitrate concentrations which showed the highest concentrations to be around the city of Mount Gambier, and in the coastal plains to the south, but the entire aquifer is essentially contaminated to some degree (Fig. 4). Levels of nitrate in the groundwater appear to be generally increasing and it has been suggested that point source pollution has played a minor role with as much as $89 \%$ of the nitrogen load coming from diffuse sources (A. G. Consulting Group, 1990).

There are thought to be hundreds of contamination plumes in the Southeast, varying in size, nature and range of contaminants. The Mil-Lel cheese factory used an old well as a liquid waste disposal site for over 80 years (Emmett \& Telfer, 1994). Groundwater monitoring at the site shows that a pollution plume about $1.5-2 \mathrm{~km}$ in length is present downstream of the factory (Fig. 5), and that it has migrated at a rate 


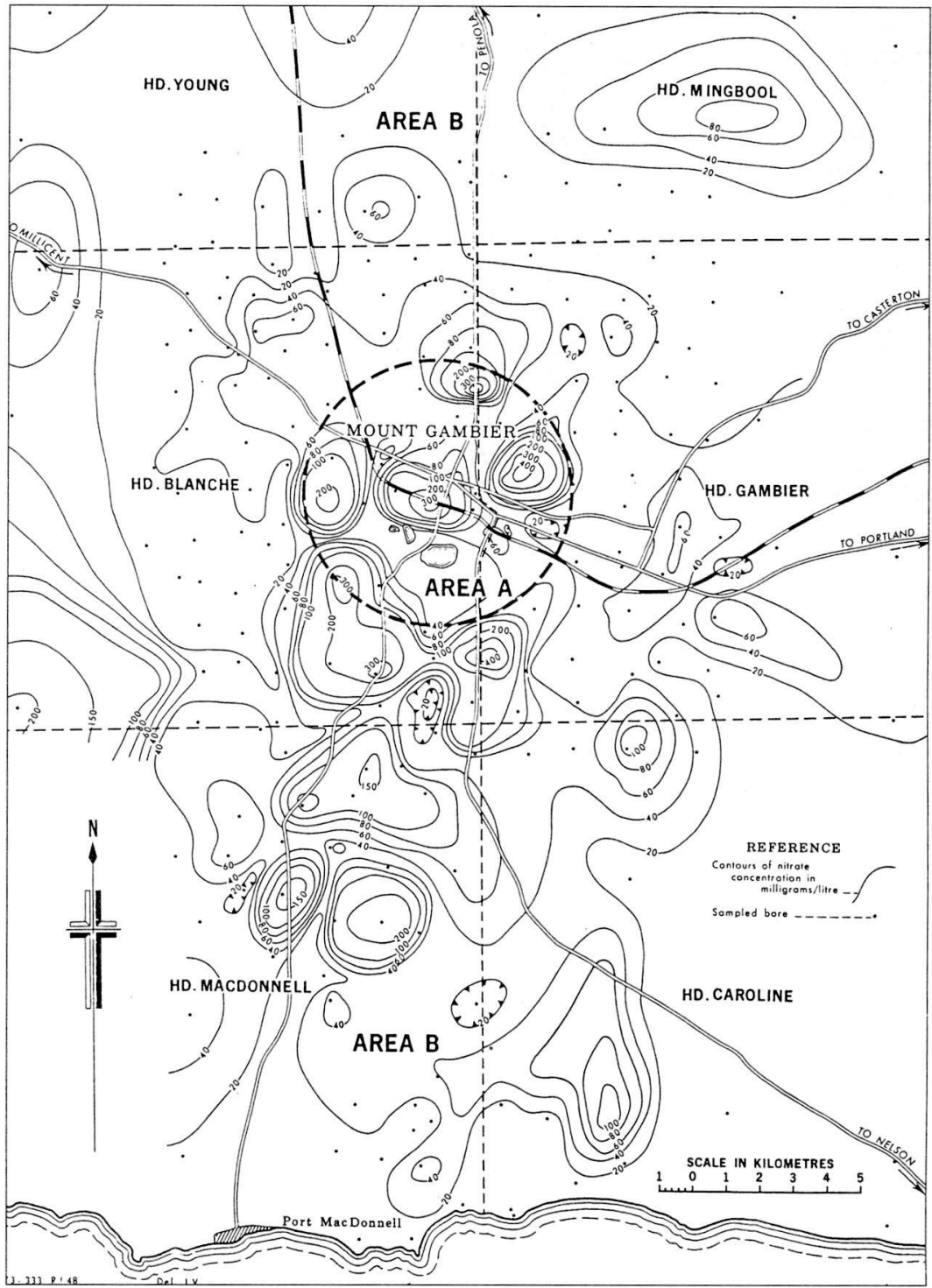

Fig. 4 - Contours of nitrate concentration in karst groundwater, South East District, South Australia. From Waterhouse, 1977.

of $40 \mathrm{~m} / \mathrm{yr}$. A cheese factory at Mount Schank, closer to the coast, also disposed of liquid wastes down excavated pits, exposed solution joints and wells (Emmett \& Telfer, 1994). Gas and polluted groundwater was evident some distance from the factory and have moved rapidly through karst voids, presumably forming another pollution plume. 


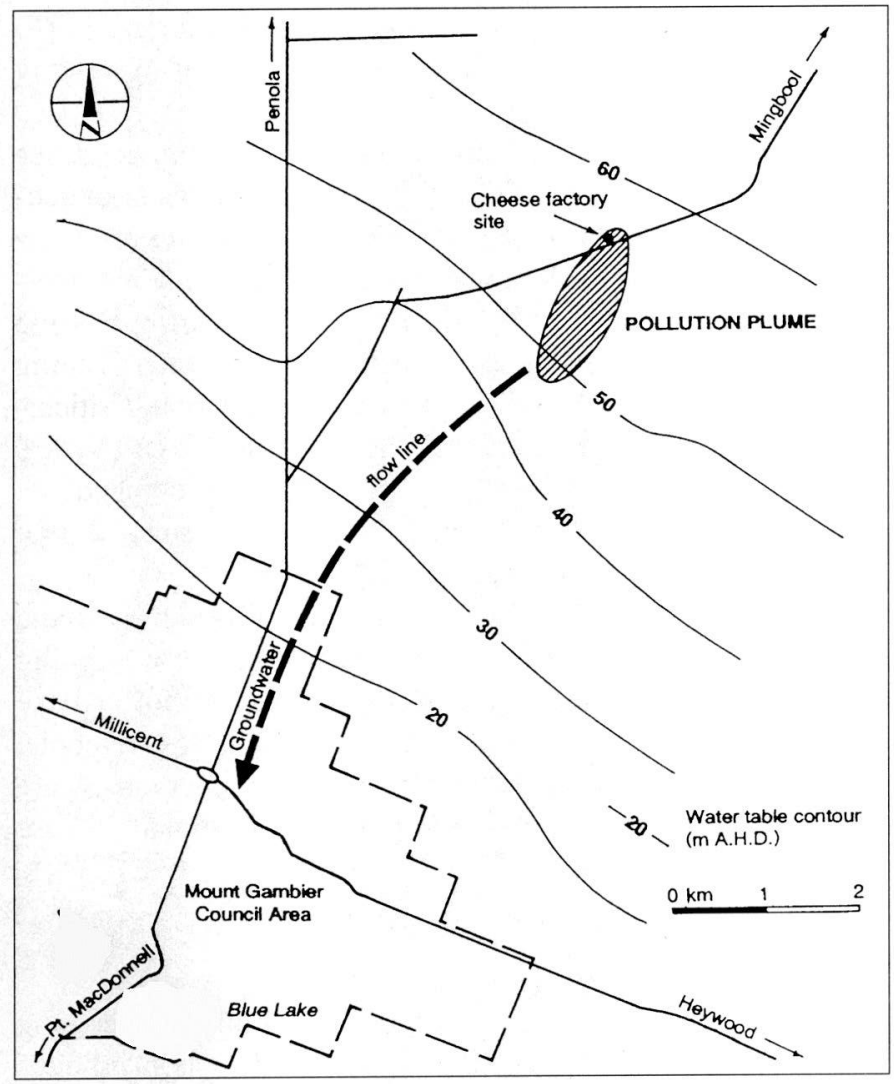

Fig. 5 - Cheese factory water plume-Mil Lel, near Mount Gambier. From Emmett and Telfer, 1994.

From the 1970s, agriculturally based industries in the Southeast, including the Mil-Lel cheese factory, adopted waste-spreading techniques in an attempt to reduce loadings of contaminants likely to leach or drain directly into the groundwater. Wastes from some intensive animal industries, dairies, piggeries, saleyards and abattoirs are now disposed of by spreading them on agricultural land. While in some instances the desired effect has been achieved, there are numerous instances where waste-spreading has continued to add to the pollution problems of the Southeast by contaminating the groundwater with nitrates and faecal bacteria. However, these contaminants are currently not migrating far from the point source, and are undoubtedly causing further pollution plumes to develop within the aquifer.

At the Mil-Lel cheese factory, several monitoring wells show nitrate concentrations between 20-60 mg/l, while another within the original plume shows levels up to $300 \mathrm{mg} / \mathrm{l}$ still present. At the Naracoorte, Millicent and Mount Gambier saleyards and at a piggery near Padthaway, waste spreading systems are causing contamination leading to escalating nitrate levels, with some sites having levels well above recommended limits. At a piggery near Myora waste-spreading is occurring over a pine 
plantation, where there is essentially no recharge to the aquifer. While this appears to be a successful method of waste disposal in this instance, the effect of harvesting when the pines mature is uncertain.

Livestock farming and plantation forestry are not the only agricultural activities to directly impact on karst groundwaters in Australia. Of all the groundwater extracted from the unconfined aquifer in the Southeast, more than $75 \%$ is used for crop irrigation. In the Padthaway region, there is concern that these supplies are being overutilised and salinity problems are occurring (Smith 1989). The Murray-Darling basin, which includes a carbonate aquifer sequence from which groundwater is being extracted, is also suffering from widespread salinity problems. A burgeoning viticulture industry in the Southeast and around the western tablelands of New South Wales, and the Margaret River region of Western Australia are placing heavy demands on groundwater supplies. Evidence is only just coming to light to suggest that groundwater supplies in these regions are being significantly depleted.

Agricultural impacts on the karst hydrology of the southeast of South Australia have now been recognised for some time, and local authorities are now working towards protecting and restoring the aquifer. While conditions appear not to have significantly worsened in recent years, there are still many problems to overcome. Generally landholders in both the public and private sector are becoming more aware of the implications of living on karst, but the pollution plumes still remain and are likely to do so for many hundreds of years.

\section{Increased sedimentation on karst and caves}

The residual soils of limestone areas in Australia have accumulated over long periods of earth history, where climatic conditions suitable for soil development have been short and the droughts leading to soil profile reduction have been the norm. The episodic nature of landscape processes on this dominantly dry continent produce pulses of sedimentation separated by long periods of minor reworking. The limestone soils are shallow, nutrient poor and that nutrient reserve is inextricably bound to soil humus. Simple clays and sesquioxides with little surface charge dominate the residual soils. Thus any erosion will lead to severe depletion of the edaphic properties of the soil.

Apart from these residual soils, many karsts have partial cover of transported soils due to a variety of geomorphic processes including fluvial transport, aeolian processes, mass movements, and cold climate conditions. In Tasmania the legacy of multiple glaciations is seen in the mantles of periglacial deposits and alluvium covering karsts (Kiernan, 1984a). These are often coarse textured, being derived from dolerite. Deep Tertiary weathering mantles overly many mainland karsts, and are very susceptible to erosion once their stabilising vegetation cover is disturbed. The development of subjacent collapse dolines in such deposits (Fig. 6) is widespread. There is thus a crucial link between landscape stability and vegetation cover on karst in Australia. Richards and Ollier (1976) record up to one metre of sediment deposi- 


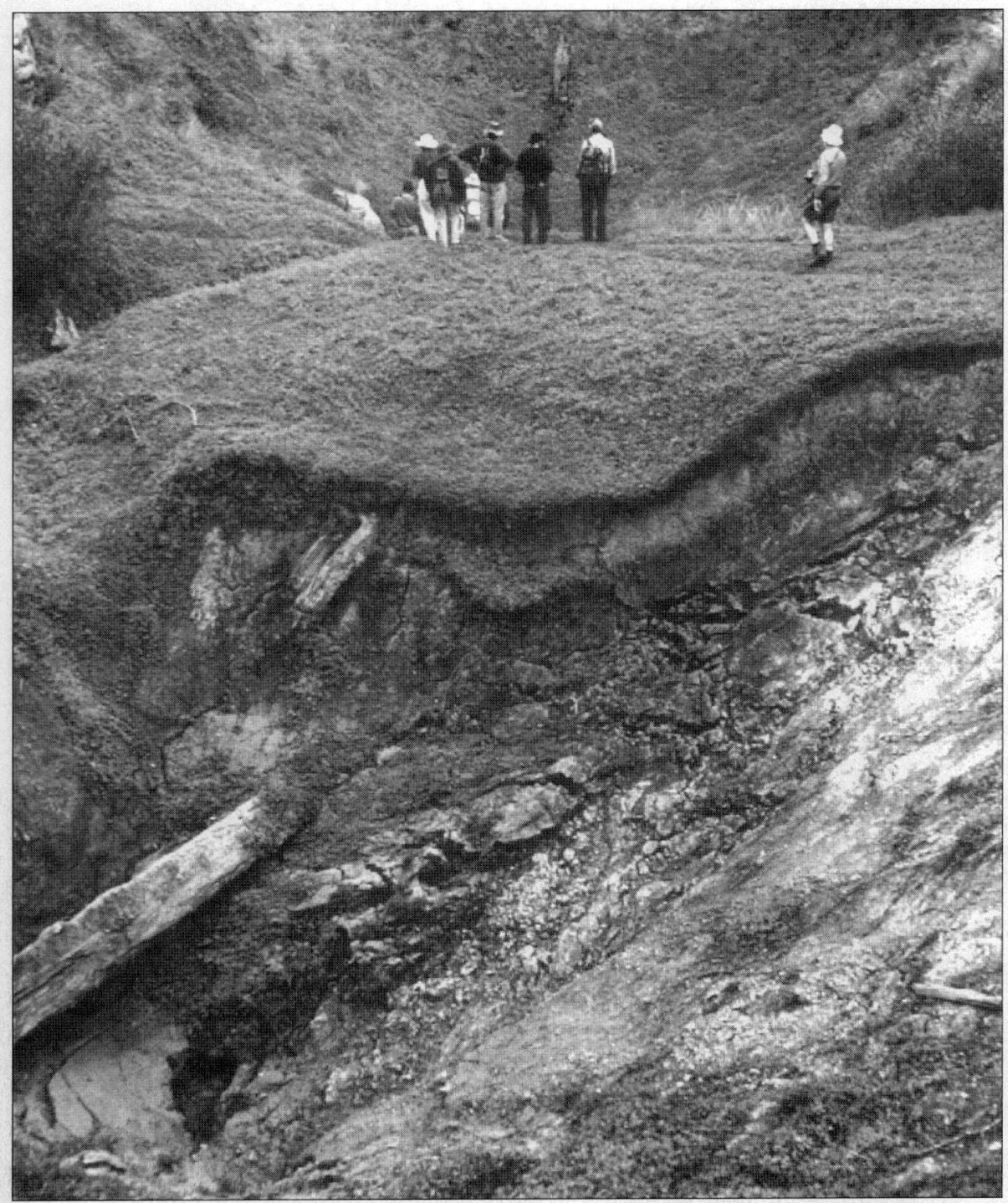

Fig. 6 - Recent subjacent collapse doline near the Loatta depression, Mole Creek, Tasmania

tion in a cave in the Florentine Valley, Tasmania following clearfelling. At Jenolan Caves in NSW, Murray et al. (1993) have used fallout radionuclides to determine the origins and rates of sedimentation in the karst hydrological system. Following clearance of native forest for pine plantations in the early $1950 \mathrm{~s}$, sedimentation rates increased to $35 \pm 14 \mathrm{~mm} / \mathrm{a}$ from an estimated post- 1939 rate of $10 \pm 3 \mathrm{~mm}$./a. Much of this increase can be attributed to the effects of intense rainstorms eroding newly established road networks in the plantation. 
Human impacts on the Mole Creek karst of Tasmania have been well documented by Kiernan (1989). The area is used for dairy cattle and sheep grazing, forestry, and quarrying of limestone for agricultural lime. The principal recent impacts on the karst are associated with land clearance for farmland, forest cutting for timber, road building, refuse disposal and associated hydrological change.

The principal impact on the karst at Loatta has been the clearance of natural vegetation and conversion to pasture over a large area of the polje floor and the nearby terraces of the Mersey River. There is abundant evidence of increased sinkhole development (Fig. 4) since clearance occurred. Kiernan (1989) considers several relevant factors. First, removal of the forest has reduced evapotranspiration leaving more soil water. Secondly, removal of tree stumps has reduced the binding agency of tree roots that stabilise the regolith overlying the limestone. Thirdly, increased soil water flow has abstracted soil fines and led to partial infilling of solution cavities and some caves. After heavy rain or the passage of a large animal, sudden failure of the ground has occurred. Runoff from impermeable road surfaces has also accentuated sinkhole development. The combination of increased runoff and impeded drainage has led to flooding of sinkholes and winter loss of available pasture on nearby flooded areas. Recent deliberate attempts to impede sinkhole drainage, and the use of allogenic irrigation water, have also changed the water balance. On steeper ground land clearance has increased soil loss, leading to some localised stripping and exposure of subsurface karren on sites such as the Dogs Head area.

There is similar evidence of agricultural impacts on karst soils in central New South Wales. Gillieson (1989) briefly described clear evidence of soil stripping on the karsts of central New South Wales, at Wellington, Orange and Molong. At Wellington rabbit bones in deep colluvium suggest a deposition date after 1865, when the animals were introduced. Frank (1972) noted the presence of an historic hearth at a depth of $40 \mathrm{~cm}$ in cave sediments at Arch Cave, Borenore, and NSW, suggesting significant deposition in the last century. There is also evidence of widespread alluvial deposition in nearby Tunnel Cave. Holland (pers. comm.) has noted the exposure of subsurface limestone pinnacles and grikes by soil erosion on cleared land at Borenore, whilst under relatively undisturbed eucalypt woodland no such soil stripping is evident. This relationship between exposed subsurface solution forms and land clearance is evident at other karst areas in central and southern New South Wales (Gillieson, 1989).

At Moore Creek, near Tamworth in the Northern Tablelands of New South Wales, Holland (1990) has recorded agricultural impacts on karst. The land has a long history of cattle grazing. Solution runnels exposed by soil surface lowering are widespread, as are terracettes on the cleared limestone hill. Solution pipes at grike intersections are infilled with soil. Other recorded impacts include the removal of limestone for lime burning, rubbish dumping and weed establishment on the cave reserve. Within Moore Creek cave, extensive pits occur due to exploration for guano deposits, and a bat colony has declined to the point of local extinction. This is also the case at the Ashford Caves near Glen Innes (Eberhard and Spate, 1995) as well as 
inwashing of large volumes of surface soil from nearby irrigated tobacco crops.

Australian limestone soils are nutrient poor in comparison to those of the younger continents (CSIRO, 1983). In most cases nutrient concentrations decline exponentially with depth, with the highest proportion in the surface $1-5 \mathrm{~cm}$. Thus the nutrient reserve is easily and severely depleted by modest erosion, and in many karst areas that erosion occurred in the nineteenth century with initial clearance and intensive use prior to the introduction of artificial fertilisers. Thus many karst areas are in a state of vegetation recovery with depleted soil resources and depauperate soil seed banks. In many karsts, the open forest or woodland dominated by species of Eucalyptus has an open understorey of grass or scattered shrubs. Continued grazing creates compaction, minor rill erosion and few seedlings survive to maturity due to grazing. This is especially true for understorey shrubs, which provide an important habitat for native birds. Native perennial grasses, such as Themeda australis and Danthonia caespitosa, are displaced in favour of exotic grasses such as Phalaris aquatica, Briza maxima and Lolium perenne. These ruderal species provide dense cover but can prove less resistant to drought, leading to periodic cover reduction and accompanying erosion. Rabbits are also a key factor in vegetation cover reduction, and the recent introduction of Rabbit Calici Virus (RCV) by the CSIRO has led to spectacular declines in their populations, especially in less humid areas. The longterm effectiveness of this biological control is unknown, and it has not spread with maintained virulence in the humid areas such as eastern New South Wales and Tasmania.

Fire management on limestone areas is a contentious subject, especially when severe wildfires have previously caused loss of life or property. In many areas fire has been widely used as a vegetation clearance tool. Most karsts have a low natural fire frequency due to the shielding effects of limestone outcrops, reduced ground cover and often a denser canopy with rainforest elements in the flora. In some karsts of eastern Australia, natural fire frequencies are poorly documented but the fire interval may be 35 to 50 years or greater (Williams \& Woinarski, 1997). Under these conditions relict vegetation types may survive, for example the rainforest understoreys of karsts in central NSW. In these karsts sediment transport only occurs immediately after fires, with minimal soil erosion in the intervening periods.

Hazard reduction burning is widely used by land managers, but may have deleterious effects on karst areas. In Australia for example many authorities aim to burn individual areas on a five to seven year cycle. This increased frequency reduces the fuel load but often promotes more fire tolerant vegetation, or changes the vegetation understorey. Thus there is potential for changes to the hydrology of the underlying karst particularly if highly organic surface soils or peat are burned. Although there may be a management prescription to avoid burning limestone outcrops, unplanned escape of fires into sensitive areas occurs due to weather changes. Increased stream siltation and cave sedimentation may result. A careful zoning of fire management, aided by mapping of past fire boundaries with buffers around karst areas, may help 
to reduce these impacts. Historical fire records using mapped data and oral histories are another valuable resource in this regard. The study of fire histories using sedimentary charcoal in caves is a promising avenue for research (Holland, 1994).

Fire is also a potent geomorphological process on limestone areas. The direct heating effect of a fire on limestone causes the removal of the rock surface as shards, which may be incorporated into the soil profile as a stone line (Holland, 1994). In tropical Australia repeated firing, on an annual basis, has caused the blunting of rillenkarren edges and the accumulation of a talus at the base of limestone bluffs. At Bendethera, NSW, fire tolerant Acacia covenyi thickets on the limestone concentrate heat close to the rock surface promoting spalling. At Mount Schank, South Australia, extensive karst pavements due to soil stripping are the products of an extensive and intense bushfire in 1939 (Holland, 1994).

\section{Cave and karst ecosystem degradation}

In Australia, the study of karst ecosystems has been slow to progress in all but a few cases, and for many areas, baseline surveys have not yet been undertaken. This poses a problem in many agricultural areas in that little is known of the nature of the ecosystems prior to European settlement, and consequently, many species may have already been lost or populations altered without prior knowledge. However, evidence is steadily building to suggest that present-day karst ecosystems are being adversely impacted by agriculture. The main processes that have been identified as having actual or potential impacts include:

- clearance of native vegetation and replacement with exotic species which alters food supplies and may cause alterations to cave climates such as desiccation;

- changes to hydrological regimes including altered flood regimes and changes to water table levels, and

- changes to water quality including increased turbidity, nutrient enrichment and the introduction of chemical pollutants.

These processes are thought to have impacted on fauna by causing losses of taxa, declines in the geographic distribution of cave communities, alterations to community composition, and alterations of community processes (Eberhard \& Spate, 1995; Eberhard \& Hamilton-Smith, 1998).

With the exception of guano from bats and cave-dwelling birds, caves ecosystems are largely dependent on external food sources. As cave environments are slow to change and relatively predictable, these ecosystems are highly vulnerable to external events, even those occurring at some distance from the cave. Clearance associated with agriculture has caused disturbances to surface environments that have affected the type and amount of food entering caves (Clarke, 1997). Clearance has either been followed by deliberate planting of exotic vegetation, or has created disturbance regimes encouraging the invasion of weedy exotics. This may mean that favoured food types are no longer available, and the new alternatives may not be palatable to the 
resident cave fauna.

The loss of leaf-litter input by conversion from forest to pasture may also be detrimental to some cave fauna. Organic inputs into the cave systems may be increased in runoff from pastures, which may favour some species, but not others. Clearing for pasture may also reduce foraging habitat for bats, causing them to abandon roosting sites and consequently decimating guanophilic communities, while causing an increase in surface insect populations, which may then have implications for the land users and their crops. There is also the potential for the dispersal opportunities of terrestrial cave species to be severely reduced, if not completely severed by conversion from forest to pasture. (Eberhard, Richardson \& Swain, 1991). Changes to cave microclimates may be brought about by vegetation clearance by altering moisture regimes. Water pollution can also impact on the gas content of the air. For fauna dependant on a particular climatic regime within a particular microhabitat, this can have devastating effects (Kiernan, 1988). Exotic pine plantations in South Australia have been found to cause dramatic changes in the level of the local water table and in cave climates. Spate (in NPWS, 1983) found qualitative evidence that caves under pines at Yarangobilly, New South Wales, have less recharge, and that cave fauna diversity and abundance are reduced in comparison to areas under native vegetation cover. These factors undoubtedly alter the environmental factors governing the location and extent of various cave fauna communities.

Changes to the hydrological regimes of karst areas have also been detrimental. When the Pike Creek Dam flooded the Texas Caves, one of the two known species of troglobitic silverfish was lost, reducing the known diversity of these animals by half (Eberhard \& Spate, 1995). Flooding of Burrinjuck Dam has also wiped out terrestrial communities, causing the abandonment of the caves by bats, which has impacted guanophilic communities and caused a reduction in biodiversity.

Changes to stream flows whether an increase or decrease in flow rate and timing, are also of concern. Doran et al (1997) suggest that changes to natural flood regimes are potentially catastrophic to associated fauna when relatively minor floods occur at unusual times, or there is an absence of floods at the expected time. Root-mat fauna of the Leeuwin-Naturaliste Ridge, Western Australia, are under threat from watertable lowering, which is due to groundwater extraction for irrigation, stock watering and consumption by rural communities (English \& Jasinska, 1998). As a consequence, these Leeuwin-Naturaliste communities which are amongst the most species-rich in the world and which contain species with Gondwanan affinities, have been listed as critically endangered.

Increased turbidity in the recharge waters of disturbed karst catchments can lead to the deposition of clays into gravel-floored cave streams. This has presumably lead to a loss of the interstitial habitat and the decline or extinction of species which were adapted to living there. Scouring of organisms with increased sediment yields is also likely during flood events. These impacts have been recorded from plantation areas in Tasmania and in caves downstream of mine sites (Clarke, 1997) and so are likely to also occur in areas under pasture. 
Clearing and fire cause the release and leaching of nutrients from the surface, leading to elevated nutrient loading in karst streams and contamination of groundwaters. This encourages bacterial multiplication, fungal growth, and in surface waters, algal blooming. Such abnormal growth situations generate high pathogen and toxin concentrations. This may cause localised extinction or reductions in species richness and biodiversity, particularly amongst highly specialised stygobionts. High nutrient levels will favour opportunistic 'polluted' water species, which may out-compete the endemic fauna (Pasquarell \& Boyer, 1991).

Eutrophication is the single greatest threat to the groundwater communities of the Southeast of South Australia. Extant stromatolite communities have been found on the walls of cenotes (water-filled sinkholes) south of Mount Gambier. These communities of great significance, particularly because an exceptionally high diversity of morphological types have been recorded, and also because of the associated stroma-

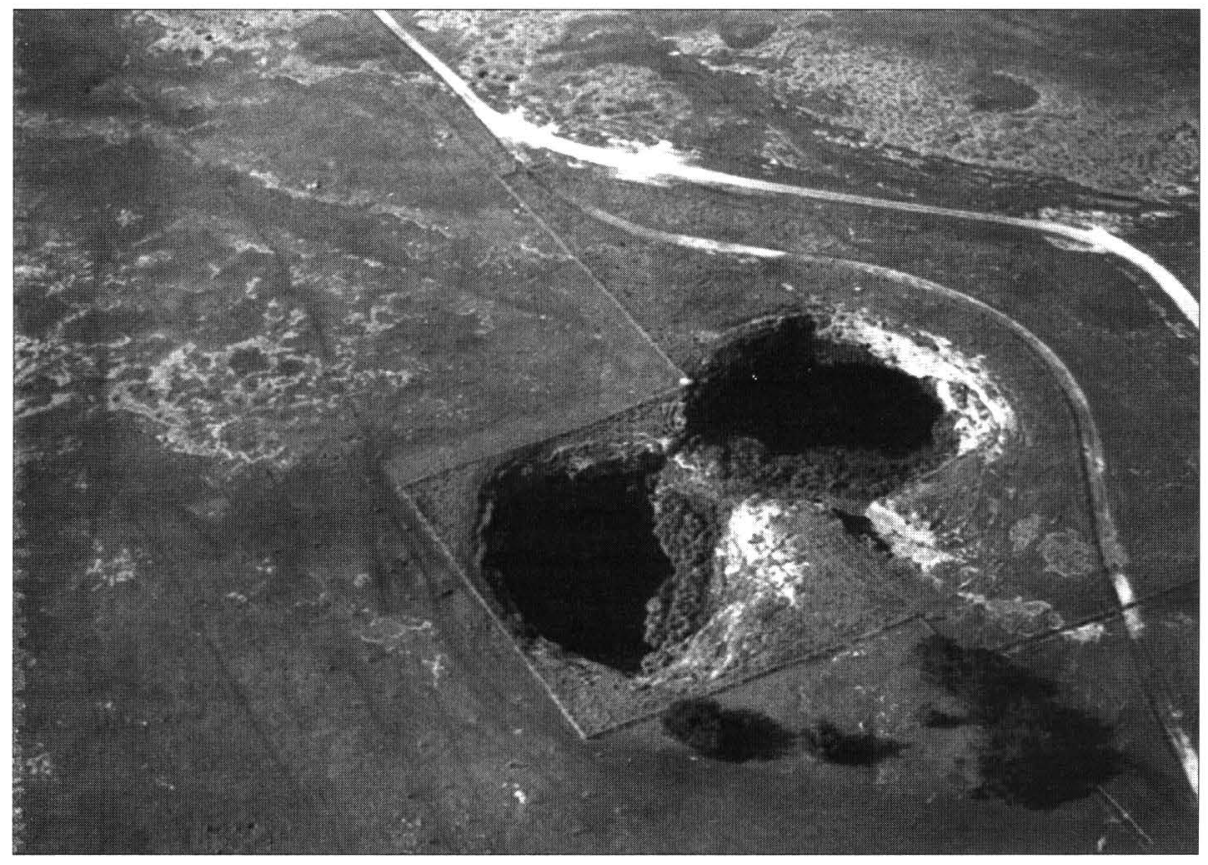

Fig. 7 - Aerial view of The Sisters cenote near Mount Gambier.

tolite-building microbial communities, which are essentially unique to each location (Thurgate, 1996). As mentioned previously, nitrate levels in the groundwater have been increasing for some time, causing an increase in the abundance and persistence of planktonic and benthic algae, especially cyanophytes (blue-green algae) which compete with the stromatolites for resources.

In the cenote known as The Sisters (Fig. 7), phytoplankton blooms are so intense in the first few metres of water during summer months that visibility is extremely 
poor, and at depth, no detectable light penetrates. Undoubtedly this interferes with photosynthetic processes in the microbial communities, and may have caused significant changes to species composition on the stromatolite surfaces. It is also possible that depositional processes, which are responsible for the 'growth' of the stromatolites, are halted during these times. In other cenote lakes, phytoplankton blooms in the water column may not be as intense, however, in Gouldens Hole and many other cenotes, thick sheets of filamentous benthic algae drape over the stromatolites and this probably has the same effect. Run-off laden with agricultural fertilisers has also caused eutrophication in Lake Clifton, Western Australia, producing algal blooms that are reducing available light levels and directly smothering the stromatolites (Eberhard \& Hamilton-Smith, 1998).

Apart from the impacts of high nutrient levels, chemical pollutants such as insecticides and herbicides (Kiernan, 1989) can also adversely effect groundwater ecosystems. The chemical control of weeds on the surface of the karst may introduce undesirable compounds into the soil, surface waters and groundwater. This may change or destroy the balance of the natural faunal communities. Using baits and poisons on the karst surface to control feral animal populations could also potentially impact on cave populations if these materials seep underground.

\section{Conclusions}

The evaluation of the impacts of agriculture on Australian karsts needs more work, for at present few empirical studies have been made. With the exception of southeastern South Australia, little monitoring of karst groundwater has been carried out. Two major areas of change have long term implications for this issue:

\subsection{Implications of changing land use and agricultural restructuring}

Australian agriculture is in the throes of major change, necessitated by increased environmental awareness and changing international markets for the commodities that have been the mainstay of the national economy. This is manifest in several key areas:

- The introduction of "smart farming" techniques, including minimal tillage, laser levelling of fields, more efficient water use, and limited use of fertilisers and herbicides, are all factors that in the long term will reduce the pressure on karst resources.

- The growth of Landcare groups in most rural areas can be viewed as a very positive move to promote a responsible, informed "grass roots" approach to land management. Such groups frequently seek the advice of qualified karst managers for training and specific advice, for example at the Borenore karst in NSW.

- The increased use of irrigation to produce high value crops is equivocal. Many new operations use flood irrigation within large bunds. These use more water and evaporation can be high. However a move away from traditional dryland farming may reduce the erosional impacts of drought conditions. Catchment management officers have now been appointed in many areas, and their monitoring programs will 
ultimately reveal the effects of these changes on karst hydrology.

- There has been a profound demographic change in rural areas, with an ageing population and widespread amalgamation of farms. More properties are owned by companies who appoint managers and are better capitalised. Such operations are more likely to innovate and seek the advice of professional karst managers.

\subsection{Implications of climatic change}

Australia is climatically a very variable continent. Even in the relatively wellwatered coastal regions, the coefficient of variability of rainfall is often as much as $20 \%$. For karst areas, this means quite dramatic fluctuations in water levels on a seasonal or annual basis. Increased extraction of karst groundwater for irrigation may severely impact on cave fauna, as well as promoting increase sediment transfers underground. Drought-breaking rains are often of high intensity, producing a pulse of sedimentation from catchment areas that have reduced vegetation cover. Predictions of net primary productivity under global warming by Henderson-Sellers \& Blong (1989) suggest that coastal areas in southwestern Australia and the coastal fringe of southeastern Australia may experience reduced or more variable vegetation growth, which may exacerbate the problem. Increased bushfire risk under dry conditions may also destabilise the land surface resulting in increase erosion. It is therefore imperative that catchment management is undertaken with this future uncertainty in mind, so as to minimise the effects of increased climatic variability on altered karst geomorphic regimes.

\section{REFERENCES}

A. G. CONSULTING GROUP PTY LTD., 1990. A Review of Groundwater Quality and Its Management in the South East of South Australia. Unpublished report to SA Electricity and Water Supply Dept, Adelaide.

ALLISON G.B. and HUGHES M.W., 1972. Comparison of recharge to groundwater under forest and pasture using Tritium. J. Hydrol. 17: 81-95.

CLARKE A., 1997. Management Prescriptions for Tasmania's Cave Fauna. Report to Tasmanian RFA Environment and Heritage Technical Committee, Zoology Department, University of Tasmania.

COLVILLE J.S. and HOLMES J.W., 1972. Water table fluctuations under forest and pasture in a karstic region of southern Australia, J. Hydrol. 17: 61-80.

CSIRO DIVISION OF SOILS, 1983. Soils: An Australian Viewpoint, Melbourne, CSIRO Publications.

DAVEY A. and WHITE S., 1986. Management of Victorian Caves and Karst: a Report to the Department of Conservation, Forests and Lands. Canberra, A. C. T., Applied Natural Resource Management.

DORAN N. E., EBERHARD S. M., RICHARDSON A. M. M. and SWAIN R., 1997. Invertebrate Biodiversity and Conservation in Tasmanian Caves. Memoirs of the Museum of Victoria 56 (2): 649-653.

EBERHARD S. and HAMILTON-SMITH E., 1998. Conservation of Cave Fauna in Australia. In Proc. of the Twelfth Australasian Conference on Cave and Karst Managment (Waitomo, New Zealand), pp. 15-30. 
EBERHARD R., 1994. Inventory and Management of the Junee River Karst System. Forestry Tasmania, Hobart.

EBERHARD S. M., RICHARDSON A. M. M. and SWAIN R., 1991. The Invertebrate Cave Fauna of Tasmania. Zoology Department, University of Tasmania, Hobart.

EBERHARD S. and SPATE A., 1995. Cave Invertebrate Survey: Toward an Atlas of NSW Cave Fauna. NSW National Parks \& Wildlife Service, Sydney.

EMMETT A.J. and TELFER A. L., 1994. Influence of karst hydrology on water quality management in southeast South Australia, Environmental Geology 23: 149-155.

ENGLISH V. and JASINSKA E., 1998. Biodiversity in Minature: the Threatened Wildlife of Caves. Landscope 13 (4): 42.

FRANK R.M., 1972. Sedimentary and morphological development of the Borenore Caves, New South Wales (part I). Helictite 10 (4): 75-90.

GILLIESON D., 1993. Environmental Change and Human Impact on Arid and Semi-arid Karsts of Australia. In Williams P.(ed.), Karst Terrains: Environmental Changes and Human Impact, Catena Supplement 25: 127-146.

GILLIESON D., 1989. Effects of land use on karst areas of Australia. In Gillieson D. and Ingle Smith D., Resource Management in Limestone Landscapes: International Perspectives, Special Publication 2, Dept. Geogr. Oceanogr., University College, UNSW, pp 43-60.

GILLIESON D. and SPATE A., 1998. Karst and caves in Australia and New Guinea In Yuan Daoxian (ed.), Global Karst Correlation, VSP Press, Utrecht, 229-254.

GRIMES K.G., 1994. The South-East Karst Province of South Australia. Environmental Geology 23: 134-148.

HENDERSON-SELLERS A., and BLONG R., 1989. The Greenhouse Effect. Living in a Warmer Australia, UNSW Press, Sydney.

HOLLAND E., 1990. Moore Creek Reserve Karst and Caves Study. Unpublished Report for Department of Lands, Tamworth NSW, Bathurst, Jenolan Caves Reserve Trust.

HOLLAND E. A., 1991. Borenore Caves Reserve: Resource Guidelines for the Mt. Canobolas Trust. Unpublished report, Jenolan Caves Reserve Trust.

HOLLAND E., 1994. The effects of fire on soluble rock landscapes. Helictite 32 (1): 3-9.

HORNE P., 1993. Lower South East Cave Reference Book: an Illustrated Catalogue of the Registered Caves, Sinkholes and Associated Karst Features of the Lower South East Region of South Australia. Peter Horne and the Cave Exploration Group of South Australia (Inc), Adelaide.

JENNINGS J. N., 1975. How well off is Australia for caves and karst? A brief geomorphic estimate. Proc. 10th. Aust. Speleol. Fedn. Conf., 82-90.

JENNINGS J. N., 1983. A Map of Karst Cave Areas in Australia. Australian Geographical Studies 21 (2) :183-96.

JONES W., 1978. The Wetlands of the South-East of South Australia. Nature Conservation Society of South Australia.

KIERNAN K., 1984a. Glaciation and karst in Tasmania: review and speculations. Helictite 20: 11-16.

KIERNAN K., 1984b. Land-use in Karst Areas: Forestry Operations and the Mole Creek Caves. Forestry Commission and National Parks \& Wildlife Service, Hobart.

KIERNAN K., 1988. The Management of Soluble Rock Landscapes: an Australian Perspective. Speleol. Res. Council, Sydney.

KIERNAN K., 1989. Karst, Caves, and Management at Mole Creek. Tasmania, Hobart, Department of Parks, Wildlife \& Heritage Occasional Paper No. 22.

KIERNAN K., 1996. An atlas of tasmanian karst. Tasmanian Forest Research Council, 
Inc., Research Report No. 10, Vol 1 \& Vol. 2, Hobart.

LICHON M., 1993. Human impacts on processes in karst terranes, with special reference to Tasmania. Cave Science 20 (2): 53-60.

MURRAY A.S., STANTON R., OLLEY J.M., and MORTON R., 1993. Determining the origins and history of sedimentation in an underground river system using natural and fallout radionuclides. Journal of Hydrology 146: 341-359.

N.P.W.S., 1983. Harvesting and Rehabilitation of Jounama Pine Plantation. Kosciusko National Park - Environmental Impact Statement, N.P.W.S. and Forestry Commission, Sydney.

OSBORNE R.A.L., and BRANAGAN D.F., 1988. Karst Landscapes of New South Wales, Australia. Earth Science Reviews 25: 467-480.

PASQUARELL G. C., and BOYER D. B., 1991. Water quality impacts of agriculture on karst conduit waters, Greenbrier County, WV. In FOSTER D. L. (ed), National Cave Management Symposium Proceedings. American Cave Conservation Association. Kentucky.

RICHARDS A.M. and OLLIER C.D., 1976. Investigation and Report of the Ecologcial Protection of Exit Cave near Ida Bay in Tasmania. Unpublished report to National Parks \& Wildlife Service, Hobart.

SMITH D.I., 1989. Carbonate aquifers in Australia: a review. In GILLIESON D. and INGLE SMITH D., Resource Management in Limestone Landscapes: International Perspectives, Special Publication 2, Dept. Geogr. Oceanogr., University College, Aust. Def. Force. Acad., 15-41.

THURGATE M., 1995. Sinkholes, Caves and Spring Lakes. South Australian Underwater Speloelogical Society Occasional Paper Number 1, Adelaide.

TRANTER J., GUNN J. and HUNTER C., 1997. An initial assessment of sanitary bacterial dynamics in the Castleton karst, Derbyshire. In GUNAY G. and Johnson A.I. (eds.), Karst Waters and Environmental Impacts, A.A. Balkema, Rotterdam, 125-130.

WATERHOUSE J. D., 1977. The Hydrogeology of the Mount Gambier Area. Department of Mines, Geological Survey of South Australia, Adelaide.

WILLIAMS M., 1974. The Draining of the Swamps in The Making of the South Australian Landscape: a Study in the Historical Geography of Australia. Academic Press, London, pp 178-226.

WILLIAMS P.W., 1993. Environmental Change and Human Impact on Karst Terrains: An Introduction. In WILLIAMS P. (ed.), Karst Terrains: Environmental Changes and Human Impact, Catena Supplement 25: 1-20.

WILLIAMS. J. and WOINARSKI J., 1997. Eucalypt ecology: individuals to ecosystems. Cambridge University Press. 